\title{
Efficiency of the bicycle operation under various tactical variants
}

\author{
Kolumbet A.N. ${ }^{1}$, Bazulyuk T.A. ${ }^{1}$, Dudorova L.Y. ${ }^{1}$, Chernovsky S.M. ${ }^{1}$, Maximovich N.Y. ${ }^{2}$ \\ ${ }^{1}$ Kiev National University of Technology and Design, Ukraine \\ ${ }^{2}$ National University “Odessa Academy of Law”, Ukraine
}

\begin{abstract}
Purpose:

Material: $\quad$ In the experiments participated athletes $(n=6)$ of high qualification (mean age $-19.8 \pm 1.3$ years, mean weight $71.4 \pm 3.5 \mathrm{~kg}$ ). As a model of the individual pursuit race at $4 \mathrm{~km}$, a five-minute pedaling on the bicycle ergometer was used. Series of loads was set on the modernized mechanical bicycle ergometer "Monark". The five-minute bicycle ergometer test is similar to the individual pursuit race at $4 \mathrm{~km}$ : according to the time of the exercise; on the frequency of pedaling (110-120 rpm); on the frequency of heartbeats.

Results: $\quad$ Tactical variants in the pursuit race at $4 \mathrm{~km}$ are considered. The total work in a free test was on average $106.38 \pm$ $3.57 \mathrm{~kJ}$. The operating energy consumption is on average for $379.0 \pm 16.1 \mathrm{~kJ}$. The operating efficiency (economy) of the exercise attained on average for $28.0 \pm 0.75 \%$. This corresponds to the effectiveness of aerobic work of moderate power. The ratio of aerobic and anaerobic contributions to the provision of work was 77.3 and $22.7 \%$. The smallest work was done in a test with step-increasing power. The athletes performed the closest work to the given job in the test with a variable $( \pm 15 \%)$ operating mode. The shortfall in it was on average for $0.46 \%$. The absence of reliable differences in the economics of the work did not allow us to identify a rational variant of power distribution for an exercise lasting 5 minutes.

Conclusions: Tactical options in the pursuit race for $4 \mathrm{~km}$ depend on the features of the power systems of the rider. When optimizing tactics, it is necessary to select an individually optimal variant of the distribution of forces at a distance. cycling, tactics, energy expenditure, economy, aerobic, anaerobic

Keywords:
\end{abstract}

\section{Introduction}

Many experts recognize the need for scientifically based development of optimal layout of the passage of individual distances $[1,5]$. To solve this problem by means of pedagogical observations and analysis of performances of athletes at the competitions is not completely possible. All the recommended distances are largely hypothetical. The objective comparison of the various tactical options have not much attempts $[3,8,12]$. The loads in these studies were not applied to the limit. This reduced the importance of the received information for the practice of sports.

Economy is the most common criterion of optimality. Economic efficiency quantitatively characterizes the ratio of the result of activity and an expenditure of achieving this result [16]. Quantitative indicator of the economy of movements is considered to be the mechanical efficiency of the work. Mechanical efficiency is calculated as the ratio of the useful work to the energy expended. For the quantitative estimation of profitability, varieties of the coefficient of mechanical efficiency are used [16]. The expenditure of moving segments of the moving person body is taken into account in determining the operational efficiency [3]. When pedaling on the bicycle ergometer, the overall efficiency factor does not exceed $20 \div 22 \%$, the net efficiency factor is $25 \%[11,15]$.

Tactical variety of options for the action of athletes is most fully manifested in competitive activities. Equally important is the use of the competitive method in training athletes [21], in physical education classes for students [20, 29, 35], and schoolchildren [18, 24, 37]. The effectiveness of such occupations depends on psychological factors [26, 44], the emotional state of athletes [34], the attractiveness of physical exercises [32, 33]. The success of athletes in competitive activity will (c) Kolumbet A.N., Bazulyuk T.A., Dudorova L.Y., Chernovsky

S.M., Maximovich N.Y. , 2017

doi:10.15561/20755279.2017.0504 be determined by morphofunctional features $[25,36$, 38], individual characteristics of physical fitness [40], physiological and energy indicators [42], performance [41].

To optimize the competitive activities in cycling, it is necessary:

- to determine the energy cost of limiting work in a given power zone [6];

- to determine the profitability of limiting work in a given power zone [7];

- to reveal the ratio of the contributions of various energy mechanisms that ensure the performance of competitive exercises [14];

- to compare the energy cost of limiting work under different tactical options [13].

An aim of the work is to determine the efficiency of the cyclist's work with various tactical options.

\section{Material and methods}

Participants. In the experiments participated athletes $(\mathrm{n}=6)$ of high qualification (mean age $-19.8 \pm 1.3$ years, mean weight $-71.4 \pm 3.5 \mathrm{~kg}$ ).

Organization of the study.

As a model of the individual pursuit race at $4 \mathrm{~km}$, a five-minute pedaling on the bicycle ergometer was used. Series of loads was set on the modernized mechanical bicycle ergometer "Monark". The five-minute bicycle ergometer test is similar to the individual pursuit race at $4 \mathrm{~km}$ : according to the time of the exercise; on the frequency of pedaling (110-120 rpm); on the frequency of heartbeats. This made it possible to follow the dynamics of the performance of athletes. Individual abilities of athletes were revealed $[10,11]$.

Determined performance in a specific area of relative power. The load conditions were calculated. Athletes should perform the maximum amount of work in 5 minutes: forced resistance and arbitrary distribution of the 
pedaling frequency (free test). In the following tests: the given operating modes were calculated from the total work done by the athlete in free test. The change in the power of work was carried out by adjusting the force on the pedals of the bicycle ergometer. The speed of the pedals was kept constant for the whole exercise. The speed of the pedals is equal to the average pedaling frequency in free test. The athletes performed the following modes of operation: fixed power $(A)$, high power mode at the beginning of exercise $(B)$, step-increasing $(C)$ power, variable power (D). The frequency of pedaling was controlled by athletes on the speedometer and recorded by the indicators of the electromechanical speed counter. Variants of work (except $D$ ) corresponded to the basic tactical layout of the athletes' distance in the individual pursuit race at $4 \mathrm{~km}$ [9].

The oxygen and carbon dioxide content of the air samples was determined on the Beckman analyzer. The volume of exhaled air was established using a dry spirometer. Calculation of consumed oxygen was carried out according to the standard procedure [17]. Analysis of samples of capillary blood (before and after the load), was carried out according to the Barker-Simmerson method in the Strohm modification [17]. The calculation of working energy expenditure was determined by summing up energy supply sources [17].

The following were recorded: pulse $\left(f_{h}\right)$, oxygen consumption $\left(\mathrm{VO}_{2}\right)$ and carbon dioxide emission, quantity $(A)$ and power $(N)$ of the work performed. The following were determined: the level of lactate ( $L a c)$ in the athlete's blood; oxygen debt; oxygen cost per unit of work $\left(\mathrm{VO}_{2} / \mathrm{A}\right)$; the oxygen demand for the work performed $\left(\mathrm{ZO}_{2}\right)$ and the oxygen deficit $\left(\mathrm{DO}_{2}\right)$.

\section{Results}

All 6 athletes did not perform free test with a uniform layout. Graph $A$ (Fig. 1,2) shows the dynamics of power work for 30 -second segments (according to average data). The athletes performed the highest work in the first 30 seconds. At the same time, the average working level exceeded $17.5 \%$. The lowest power level was maintained on the 8 th and 9 th segments. The change in capacity was $9.1 \%$.

The greatest "underfulfillment" in tests with preset regimens was noted at the same site of the exercise (ie, from 3.5 to 4.5 minutes).

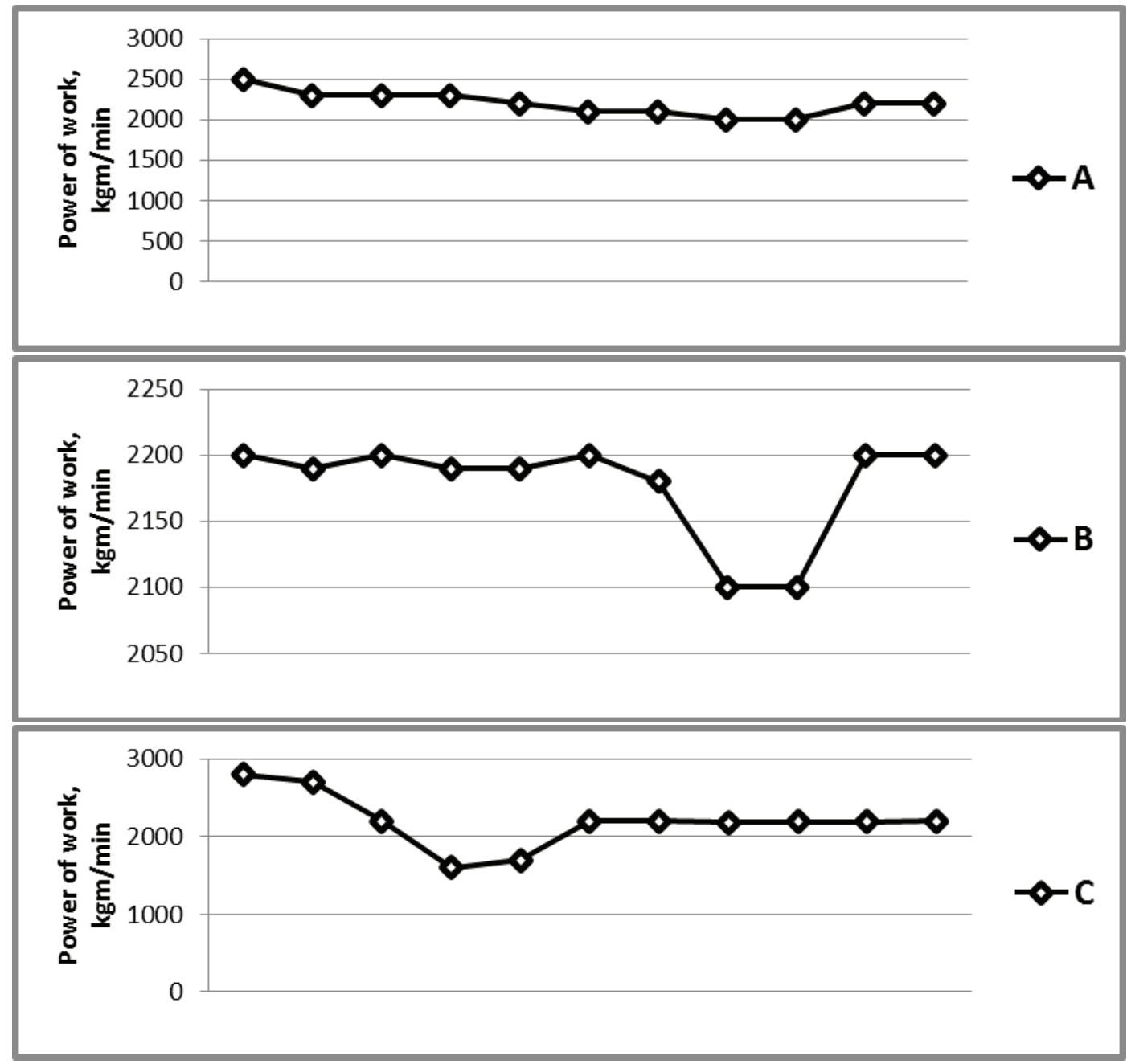

Fig. 1. Distribution of the actual pedal power at 30-second intervals: $A-$ free test; $B-$ fixed power test; $C-$ test with intensive start. 


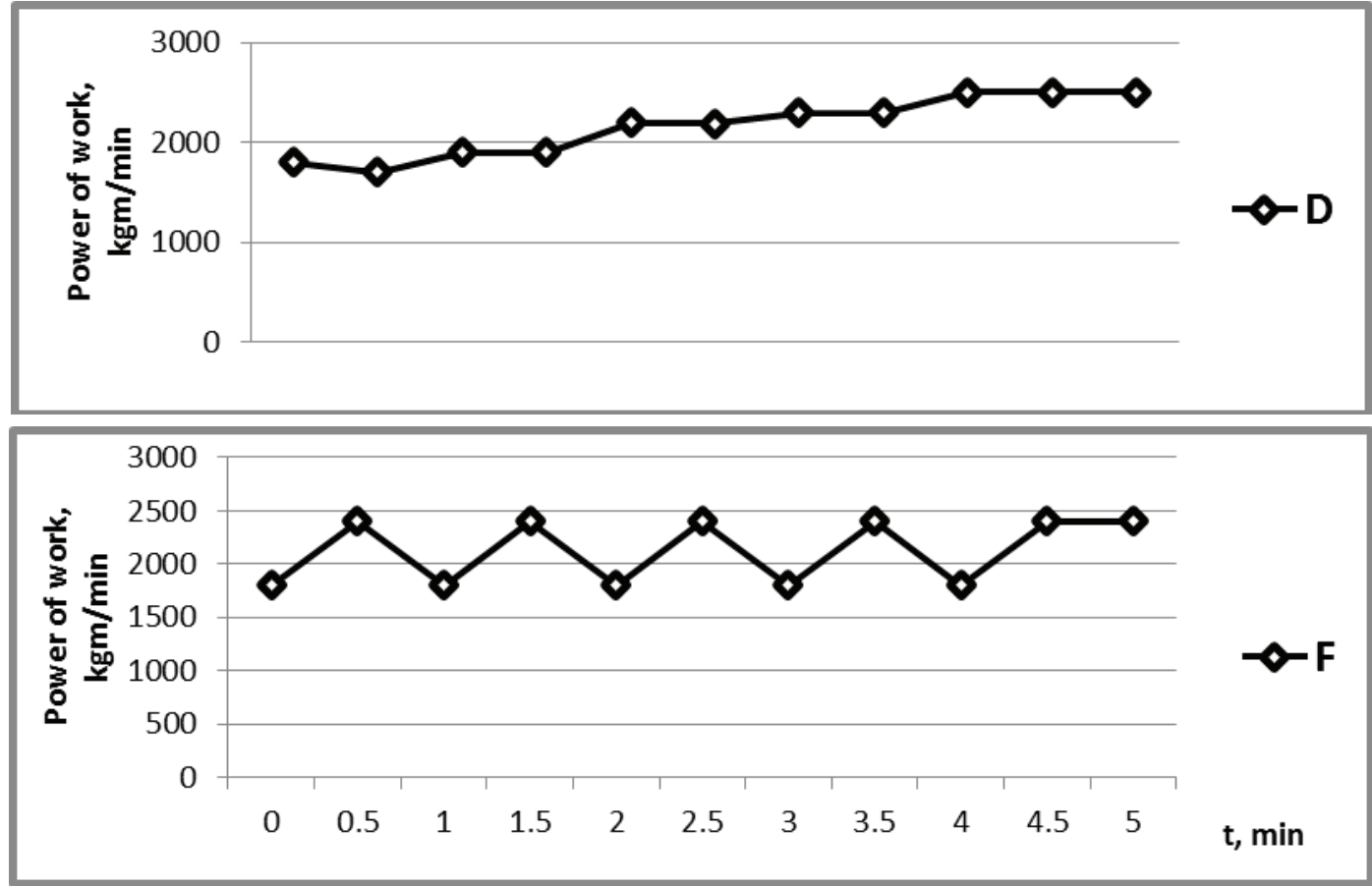

Fig. 2. Distribution of the actual pedal power at 30-second intervals: $D-$ step-increasing power test; $F-$ variable power test.

The total work in free test was on average for $106.38 \pm 3.57 \mathrm{~kJ}$. The operating energy consumption is on average for $379.0 \pm 16.1 \mathrm{~kJ}$. The working efficiency (economy) of the exercise is on average for $28.0 \pm 0.75 \%$. This corresponds to the effectiveness of aerobic work of moderate power.

The ratio of aerobic and anaerobic contributions to the provision of work was 77.3 and $22.7 \%$, respectively. The smallest work was done in a test with step-increasing power. The athletes performed the closest work to the given work in the test with a variable $( \pm 15 \%)$ operating mode. The shortfall in it was, on average, $0.46 \%$. The lactate component contributed the greatest contribution to free test and test with fixed power. Alaktat component contributed the most to loads with variable and increasing power. The aerobic component had the greatest influence in exercises with an overestimated onset (Table 1).

The absence of reliable differences in the economics of the work did not allow us to identify a rational variant of power distribution for an exercise lasting 5 minutes. Working with a fixed power did not find advantages over other options.

At different athletes the most effective were the tests with different layout options (Table 2). For L-V athlete the most preferable was variable-power work. In it, he was

Table 1. Total energy expenditure (KJ) ratio of various components of energy production (\%)

\begin{tabular}{lllll}
\hline Tests & $\begin{array}{l}\text { Operating energy } \\
\text { consumption }\end{array}$ & Aerobic & Alaktat & Lactate \\
\hline Free & 377,7 & 77,3 & 7,5 & 15,2 \\
With fixed power & 387,9 & 77,3 & 7,6 & 15,1 \\
With intensive start & 387,7 & 80,0 & 7,2 & 12,8 \\
With step-increasing & 384,8 & 78,4 & 8,0 & 13,6 \\
power & 378,7 & 78,0 & 8,0 & 14,0 \\
Variable & &
\end{tabular}

Table 2. Individual ranking of indicators of the performed work (I, II, III, IV) and economy (1, 2, 3, 4, 5)

\begin{tabular}{|c|c|c|c|c|c|}
\hline Athletes & $\begin{array}{l}\text { Tests } \\
\text { Free, } \\
\text { A }\end{array}$ & $\begin{array}{l}\text { With fixed } \\
\text { power, } \\
\text { B }\end{array}$ & $\begin{array}{l}\text { With step- } \\
\text { increasing power, } \\
\text { C }\end{array}$ & $\begin{array}{l}\text { With intensive } \\
\text { start, } \\
\text { D }\end{array}$ & $\begin{array}{l}\text { Variable, } \\
\text { F }\end{array}$ \\
\hline $\mathrm{N}-\mathrm{v}$ & 2 & $1 / 4$ & $\mathrm{IV} / 1$ & $\mathrm{III} / 5$ & $\mathrm{II} / 2$ \\
\hline K-v & 3 & II/1 & $\mathrm{IV} / 5$ & $\mathrm{III} / 2$ & $1 / 4$ \\
\hline G-h & 1 & $1 / 2$ & $\mathrm{IV} / 4$ & $\mathrm{III} / 5$ & $11 / 3$ \\
\hline L-V & 1 & $\mathrm{III} / 5$ & $11 / 3$ & $\mathrm{IV} / 4$ & $1 / 2$ \\
\hline$B-v$ & 4 & $\mathrm{IV} / 5$ & $\mathrm{III} / 2$ & $1 / 3$ & $I / 1$ \\
\hline $\mathrm{O}-\mathrm{v}$ & 1 & $\mathrm{III} / 4$ & $\mathrm{~V} / 5$ & $11 / 2$ & $1 / 3$ \\
\hline
\end{tabular}


able to perform the full amount of work with economy, which is slightly inferior to the economy in free test. For athlete G-h, the most effective was working with a fixed power.

\section{Discussion}

In studies of cycling problems, it was found that the relationship between recovery and stress factors varies greatly over a relatively short period of time. These factors dynamically affect performance in multi-stage competitions [22]. Other studies have shown that the increase in performance of athletes is affected by: the level of self-esteem [23], the use of feedback for decisionmaking [27]; planned adaptation to endurance training [31]; psychosocial factors [46]. The results obtained by us confirm the necessity of taking into account various factors for increasing the productivity of athletes.

In a study by Waldron M. et al. [45] was highlighted the sprint characteristics of cyclists, which can be explained by mechanical and anthropometric parameters. The authors cite tests and equations that can be taken by trainers to predict performance and determine the appropriate intensity of training. Bini R.R. et al. have developed a model of a strategy to mitigate asymmetry in pedaling [19]. Knaier R. et al. have investigated the effect of bright or blue light on the maximum speed of cycling in a 12-minute test [28]. This approach allows elitist athletes to better support work during the 12-minute cycle. Leruite M. et. al. have determined the average socio-demographic profile of cyclists and triathletes [30]. The authors propose to change the policy in the sports federations, as well as initiatives to improve the competition conditions for these athletes. Pollastri L. et. al. have investigated the interrelation of water consumption with a maximum capacity of different duration of time [39]. The authors note that due to improved thermoregulation, the productivity at the last stages increases. Turpin N.A. et al. have evaluated muscle activity in a wide range of output powers for sedentary and standing positions on a bicycle [43]. The authors note that the number and structure of muscle synergism play secondary role in using standing position when pedaling at high power outputs. Such approaches in many respects coincide with our ideas about modeling the training of cyclists.

According to some studies $[1,3]$, the coefficient of overall economy of work is $22-25 \%$, the coefficient of net profitability is $26-28 \%$. The results of our study are close to these values. The total work in free test was on average for $106.38 \pm 3.57 \mathrm{~kJ}$. In the studies of other authors the similar results were obtained $[2,16]$. The ratio of aerobic and anaerobic contributions to the provision of work was $77.3 \%$ and $22.7 \%$, respectively. This is close to the ratio that was obtained by R. Astrand and K. Rodahl [4]. The received data confirm mobilization of all mechanisms of power supply.

\section{Conclusions}

1. Tactical options in the pursuit race at $4 \mathrm{~km}$ are defined as individually optimal.

2. Tactical options in the pursuit race for $4 \mathrm{~km}$ depend on the features of the power systems of the rider.

3. When optimizing tactics, it is necessary to select an individual-optimal variant of the distribution of forces at a distance.

\section{Conflict of interest}

The authors state that there is no conflict of interest.

\section{References}

1. Andriunin MA, Golovachev AI, Krylatykh IuG, Utkin VL. Efficiency of the cyclist's work in modeling the individual pursuit race at $4 \mathrm{~km}$ with different force distribution options. Velosipednyj sport, 1981:44-46. (in Russian)

2. Golovachev AI, Krylatykh IuG. Monitoring the tactical preparedness of young cyclists in individual pursuit. Velosipednyj sport, 1982:42-46. (in Russian)

3. Alexandrov II, Mikhhaylova IN. Efficiency of the motor activity in cycling. Uchenye zapiski universiteta imeni P.F.Lesgafta, 2015;12(130):25-30. (in Russian)

4. Astrand PO, Rodahl K. Textbook of work physiology: physiological bases of exercise. New York, St.Lous: McGrow-Hill; 1986.

5. Baechle TR, Earle RW. Essentials of strength training and conditioning. Human Kinetics, Champaign: United States; 2008.

6. Broker JP, Kyle CR, Burke ER. Racing cyclist power requirements in the $4000 \mathrm{~m}$ individual and team pursuits. Medicine and Science in Sports and Exercise, 1999;31(11).

7. Dahmen T. Optimization of pacing strategies for cycling time trials using a smooth 6-parameter endurance model. PreOlympic Congress on Sports Science and Computer Science in Sport (IACSS2012). Liverpool: UK; 2012.

8. Erik WF, Daryl LP, Irvin EF. The science of cycling: Factors Affecting Performance. Sports Medicine, 2005;35:313-337.
9. Kolumbet AN. Dynamic of kayak rowing technique in the process of competition activity. Pedagogics, psychology, medical-biological problems of physical training and sports, 2017; 21(4): 175-179. doi:10.15561/18189172.2017.0405

10.Kolumbet AN. Study of qualified cyclists movements' coordination structure in period of overcoming fatigue during differently oriented trainings. Physical education of students, 2017; 21(2): 72-77. doi:10.15561/20755279.2017.0204

11.Kolumbet AN, Natroshvili SG, Babyna TG. The biomechanics aspects of adaptation the system of motions of highly skilled bicyclists in the process of contention activity. Pedagogics, psychology, medical-biological problems of physical training and sports, 2017;5:272-277.

12.Lukes R, Carre M, Haake S. Track Cycling: An Analytical Model. In Moritz EF, Haake S, editors. The Engineering of Sport: Springer, 2006;1:115-120.

13.Olds TS. Modelling human locomotion: applications to cycling. Sports Medicine 2001;31(7):497.

14.Sundström D, Carlsson P, Tinnsten M. On Optimization of Pacing Strategy in Road Cycling. Procedia Engineering, 2013;60:118-123.

15.Tkachenko VS. Structure of competitive activity and value of its components to achieve high performance in individual time trial race. Physical education of students, 2012;4:120 125.

16.Wilson DG. Bicycling Science, 3rd ed: London: The MIT 
Press; 2004.

17. Kolumbet AN, Dudorova LY, Babina NA, Bazulyuk TA, Chernovsky SM. Modeling of kayak athletes competition activity.Physical education of students, 2017; 21(4): 165170. doi:10.15561/20755279.2017.0403

18.Aasland E, Walseth K, Engelsrud G. The changing value of vigorous activity and the paradox of utilising exercise as punishment in physical education. Physical Education and Sport Pedagogy. 2017;22(5):490-501.

19.Bini RR, Jacques TC, Carpes FP, Vaz MA. Effectiveness of pedalling retraining in reducing bilateral pedal force asymmetries. Journal of Sports Sciences. 2017;35(14):133641.

20.Drogomeretsky VV, Kopeikina EN, Kondakov VL, Iermakov SS. Adaptation of Ruffier's test for assessment of heart workability of students with health problems. Pedagogics, psychology, medical-biological problems of physical training and sports, 2017; 21(1): 4-10. doi:10.15561/18189172.2017.0101

21.Druz VA, Iermakov SS, Nosko MO, Shesterova LYe, Novitskaya NA. The problems of students' physical training individualization. Pedagogics, psychology, medicalbiological problems of physical training and sports, 2017; 21(2): 4-12. doi:10.15561/18189172.2017.0201

22.Filho E, Di Fronso S, Forzini F, Murgia M, Agostini T, Bortoli $\mathrm{L}$, et al. Athletic performance and recovery-stress factors in cycling: An ever changing balance. European Journal of Sport Science. 2015;15(8):671-80.

23.Guy JH, Pyne DB, Deakin GB, Miller CM, Edwards AM. Acclimation Training Improves Endurance Cycling Performance in the Heat without Inducing Endotoxemia. Frontiers in Physiology. 2016;7.

24.Hastie PA, Ward JK, Brock SJ. Effect of graded competition on student opportunities for participation and success rates during a season of Sport Education. Physical Education and Sport Pedagogy. 2017;22(3):316-27.

25.Hornig M, Aust F, Gullich A. Practice and play in the development of German top-level professional football players. European Journal of Sport Science. 2016;16(1):96105.

26.Jagiello W. Differentiation of the body composition in taekwondo-ITF competitors of the men's Polish national team and direct based athletes. Archives of Budo. 2015;11:329-38.

27.Jones HS, Williams EL, Merchant D, Sparks SA, Bridge CA, Midgley AW, et al. Improvements in Cycling Time Trial Performance Are Not Sustained Following the Acute Provision of Challenging and Deceptive Feedback. Frontiers in Physiology. 2016;7.

28.Knaier R, Schafer J, Rossmeissl A, Klenk C, Hanssen H, Hochsmann C, et al. Prime Time Light Exposures Do Not Seem to Improve Maximal Physical Performance in Male Elite Athletes, but Enhance End-Spurt Performance. Frontiers in Physiology. 2017;8.

29.Kopeikina EN, Drogomeretsky VV, Kondakov VL, Kovaleva MV, Iermakov SS. Modification of harvard step-test for assessment of students' with health problems functional potentials. Physical Education of Students. 2016;20(4):4450. doi:10.15561/20755279.2016.0405

30.Leruite M, Morente-Sanchez J, Martos P, Girela MJ, Zabala M. Analysis of the sporting context of spanish female competitive cyclists and triathletes. Revista Internacional De Medicina Y Ciencias De La Actividad Fisica Y Del Deporte. 2016;16(64):667-84.

31.Mujika I, Ronnestad BR, Martin DT. Effects of Increased Muscle Strength and Muscle Mass on Endurance-Cycling
Performance. International Journal of Sports Physiology and Performance. 2016;11(3):283-9.

32.O' Brien W, Belton S, Issartel J. Fundamental movement skill proficiency amongst adolescent youth. Physical Education and Sport Pedagogy. 2016;21(6):557-71.

33.Osipov AY, Kudryavtsev MD, Kramida IE, Iermakov SS, Kuzmin VA, Sidorov LK. Modern methodic of power cardio training in students' physical education. Physical Education of Students. 2016;20(6):34-9. doi:10.15561/20755279.2016.0604

34.Osipov AYu, Kudryavtsev MD, Iermakov SS, Yanova MG, Lepilina TV, Plotnikova II, Dorzhieva OS. Comparative analysis of effectiveness of some students' physical culture training methodic. Physical education of students, 2017; 21(4): 176-181. doi:10.15561/20755279.2017.0405

35.Pedersen SJ, Cooley PD, Cruickshank VJ. Caution regarding exergames: a skill acquisition perspective. Physical Education and Sport Pedagogy. 2017;22(3):246-56.

36.Podrigalo LV, Galashko M N, Iermakov SS, Rovnaya OA, Bulashev AY. Prognostication of successfulness in armwrestling on the base of morphological functional indicators' analysis. Physical education of students, 2017; 21(1): 46-51. doi:10.15561/20755279.2017.0108

37.Podrigalo LV, Iermakov SS, Avdiievska OG, Rovnaya OA, Demochko HL. Special aspects of Ukrainian schoolchildren's eating behavior. Pedagogics, psychology, medical-biological problems of physical training and sports, 2017; 21(3): 120125. doi:10.15561/18189172.2017.0304

38.Podrigalo LV, Iermakov SS, Jagiełło W. Special indices of body composition as a criterion of somatic development of martial arts practitioners. Arch Budo Sci Martial Art Extreme Sport, 2017; 13: 5-12

39.Pollastri L, Lanfranconi F, Tredici G, Burtscher M, Gatterer H. Body Water Status and Short-term Maximal Power Output during a Multistage Road Bicycle Race (Giro d'Italia 2014). International Journal of Sports Medicine. 2016;37(4):329-33.

40.Roe G, Darrall-Jones J, Till K, Phibbs P, Read D, Weakley $\mathrm{J}$, et al. The effect of physical contact on changes in fatigue markers following rugby union field-based training. European Journal of Sport Science. 2017;17(6):647-55.

41.Roe GAB, Darrall-Jones JD, Till K, Jones B. Preseason changes in markers of lower body fatigue and performance in young professional rugby union players. European Journal of Sport Science. 2016;16(8):981-8.

42.Sindiani M, Eliakim A, Segev D, Meckel Y. The effect of two different interval-training programmes on physiological and performance indices. European Journal of Sport Science. 2017;17(7):830-7.

43.Turpin NA, Costes A, Moretto P, Watier B. Can muscle coordination explain the advantage of using the standing position during intense cycling? Journal of Science and Medicine in Sport. 2017;20(6):611-6.

44.van Aart I, Hartman E, Elferink-Gemser M, Mombarg R, Visscher C. Relations among basic psychological needs, PEmotivation and fundamental movement skills in 9-12-yearold boys and girls in Physical Education. Physical Education and Sport Pedagogy. 2017;22(1):15-34.

45. Waldron M, Gray A, Furlan N, Murphy A. Predicting the sprint performance of adolescent track cyclists using the 3-minute all-out test. Journal of Strength and Conditioning Research. 2016;30(8):2299-306.

46.Zabala M, Morente-Sanchez J, Mateo-March M, Sanabria D. Relationship Between Self-Reported Doping Behavior and Psychosocial Factors in Adult Amateur Cyclists. Sport Psychologist. 2016;30(1):68-75. 
Information about the authors:

Kolumbet A.N.; http://orcid.org/0000-0001-8775-4232; re_play@3g.ua; Kiev National University of Technology and Design; st. Nemirovich-Danchenko, 2, Kiev, 14013, Ukraine.

Bazulyuk T.A.; http://orcid.org/0000-0002-6244-6302; baziluk@rambler.ru; Kiev National University of Technology and Design; st. Nemirovich-Danchenko, 2, Kiev, 14013, Ukraine.

Dudorova L.Y.; http://orcid.org/0000-0002-6263-4995; vykh46@i.ua; Kiev National University of Technology and Design; st. Nemirovich-Danchenko, 2, Kiev, 14013, Ukraine.

Chernovsky S.M.; http://orcid.org/0000-0002-1927-9203; chernovskij.sm@knutd.com.ua; Kiev National University of Technology and Design; st. Nemirovich-Danchenko, 2, Kiev, 14013, Ukraine.

Maximovich N.Y.; http://orcid.org/0000-0002-7405-9801; natalimaximovich@i.ua; National University "Odessa Academy of Law"; Kharkov highway, 210, Kiev, 02121, Ukraine.

Cite this article as: Kolumbet AN, Bazulyuk TA, Dudorova LY, Chernovsky SM, Maximovich NY. Efficiency of the bicycle operation under various tactical variants. Physical education of students, 2017;21(5):219-224. doi:10.15561/20755279.2017.0504

The electronic version of this article is the complete one and can be found online at: http://www.sportedu.org.ua/index.php/PES/issue/archive

This is an Open Access article distributed under the terms of the Creative Commons Attribution License, which permits unrestricted use, distribution, and reproduction in any medium, provided the original work is properly cited (http://creativecommons.org/licenses/by/4.0/deed.en).

Received: 21.06.2017

Accepted: 15.07.2017; Published: 09.09.2017 